\title{
Indirect Two-Site Immunoradiometric Assay of Rat and Mouse Proinsulin
}

\author{
D. K. Yue ${ }^{1}$, O. M. Gibby², S. D. Luzio' ${ }^{2}$, N. Yanaihara ${ }^{3}$, and C. N. Hales ${ }^{2}$ \\ ${ }^{2}$ Department of Clinical Biochemistry, University of Cambridge, Addenbrooke's Hospital, Cambridge, England, \\ and ${ }^{3}$ Department of Bio-organic Biochemistry, Shizuoka College of Pharmacy, Shizuoka-Shi, Japan
}

\begin{abstract}
Summary. An indirect two-site immunoradiometric assay for rat and mouse proinsulin using a rabbit antibody to synthetic rat $C$-peptide has been developed. The sensitivity of the assay is $0.006 \mathrm{pmol} / \mathrm{ml}$. Proinsulin was $4.95 \%$ of the total proinsulin and insulin in extracts of rat pancreas and $5.45 \%$ in extracts of isolated rat islets. The mean fasting rat insulin and proinsulin concentrations were $0.13 \pm 0.09 \mathrm{pmol} / \mathrm{ml}$ $(\mathrm{n}=5)$ and $0.008 \pm 0.002 \mathrm{pmol} / \mathrm{ml}(\mathrm{n}=5)$ respectively. The mean fasting mouse proinsulin concentration was $0.019 \pm 0.006 \mathrm{pmol} / \mathrm{ml}(\mathrm{n}=8)$. In rats intravenous glucose produced a biphasic insulin response but proinsulin rose progressively to $0.021 \pm$ $0.011 \mathrm{pmol} / \mathrm{ml}$ at $45 \mathrm{~min}$. In mouse oral glucose increased the proinsulin concentration to $0.13 \mathrm{pmol} /$ $\mathrm{ml}$ at $30 \mathrm{~min}$. Proinsulin release from isolated rat islets was studied during intermittent or continuous high glucose $(20 \mathrm{mmol} / \mathrm{l})$ stimulation in static incubation. Significant increases in proinsulin release were only observed $90 \mathrm{~min}$ after initial exposure to high glucose whether glucose stimulation was continuous or intermittent. Both in vivo and in vitro glucose stimulation led initially to a fall in the proinsulin/ insulin molar ratio but later upon prolonged stimulation this progessively increased to above the basal value.
\end{abstract}

Key words: Indirect two-site immunoradiometric assay, rat proinsulin, mouse proinsulin, islets, proinsulin/insulin ratio.

The concentration of plasma proinsulin may be elevated in diabetes $[1,2]$. This abnormality could be due to chronic hyperglycaemic overstimulation of a

\footnotetext{
1 Present address: Department of Medicine, The University of Sydney, Sydney, N. S. W., Australia 2006
}

limited number of functioning $\beta$ cells. As a result insulin may be released from immature secretory granules in which conversion of proinsulin to insulin is incomplete.

Further investigation of the mechanism by which damage to or a deficiency of $\beta$ cells can affect proinsulin production and release would be greatly facilitated by the ability to study the process in animal models. However, although measurement of proinsulin concentrations can be achieved by chromatographic separation and insulin radioimmunoassay [3, 4] these procedures are very time consuming and difficult to apply to small volumes of blood from laboratory animals. The wide species variation in the structure of the C-peptide of proinsulin precludes the use of heterologous immunoassays $[5,6]$. We have devised an indirect two-site immunoradiometric assay for human proinsulin [7]. One advantage of this method is that it is immediately applicable to the assay of proinsulin in other species with the substitution of a rabbit antiserum to the appropriate C-peptide. In the study which is described below an antiserum raised against synthetic rat C-peptide in a rabbit was used to establish an assay for rat and mouse proinsulin. We also report our preliminary studies of proinsulin release in rat and mouse in vivo and in vitro.

\section{Materials and Methods}

Rabbit antiserum to rat C-peptide (R-901) was raised by immunizing rabbits with polyvinylpyrrolidone adsorbed synthetic rat C-peptide II [8]. Bovine and porcine proinsulin were gifts from Dr. Chance of the Eli Lilly Research Laboratory, Indianapolis, Indiana. Human proinsulin was provided by Dr. A. Rubenstein of the University of Chicago, Illinois. Rat insulin and a preparation of rat b-component [9] were supplied by Dr. Lise Heding of the Novo Research Institute, Copenhagen, Denmark. Collagenase was 


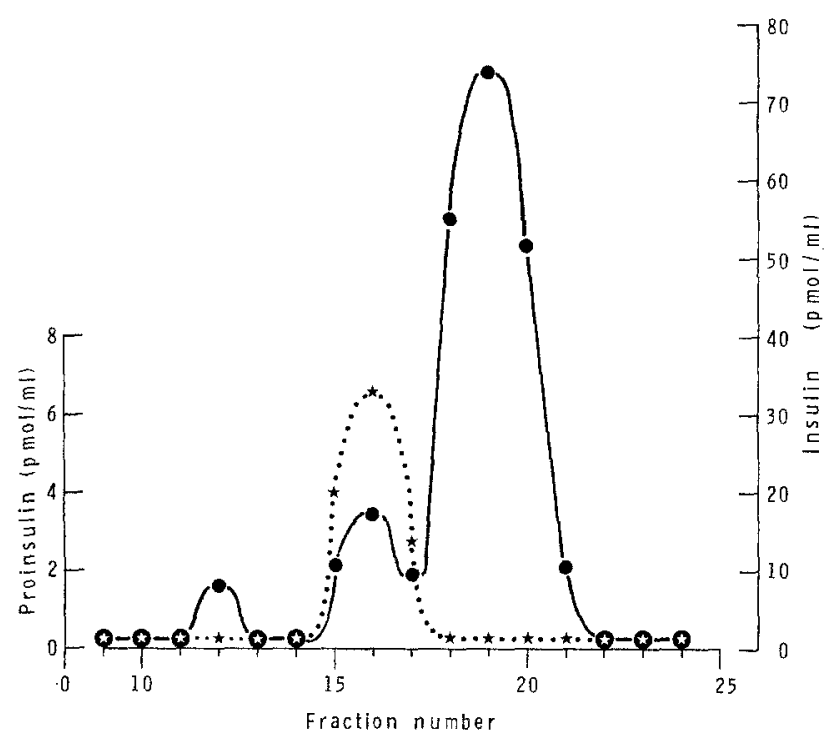

Fig. 1. Sephadex chromatography elution profile of an acidethanol extract of rat pancreas, for details see text. * proinsulin; -insulin

obtained from Sigma Chemical Co. Ltd., London, U. K. Other reagents were obtained as described previously [7] and all chemicals used were of analytical grade in purity.

\section{Proinsulin Assay}

The indirect two-site immunoradiometric assay for rat proinsulin is an adaptation of the human proinsulin assay described by us previously [7]. Proinsulin is recognised as a molecule with both an insulin and a C-peptide antigenic site. After extraction of insulin and proinsulin onto polyethylene tubes coated with excess insulin antibody the subsequent binding of rabbit antibody to rat C-peptide with proinsulin is measured by ${ }^{125}$ I-sheep antibody to rabbit IgG. The rabbit antiserum to rat $C$-peptide was used in a dilution of $1 / 1000$ and the volume of incubation was $50 \mu \mathrm{l}$. Serial dilutions of a rat bcomponent [9], produced in our laboratory, corresponding to a rat proinsulin concentration of $0.006-0.672 \mathrm{pmol} / \mathrm{ml}$ were used as standards (see below). Standards for the measurement of plasma proinsulin were made up in rat fasting plasma pretreated with insulin antibody immunoadsorbent as described previously [7]. For samples other than plasma, standard curves were set up in phosphate-buffered saline (PBS) containing $\mathrm{NaH}_{2} \mathrm{PO}_{4} / \mathrm{Na}_{2} \mathrm{HPO}_{4}$ $0.05 \mathrm{~mol} / 1, \mathrm{NaCl} 0.15 \mathrm{~mol} / \mathrm{l}, \mathrm{pH} 7.4$. The coating of polyethylene tubes with guinea-pig antibody to insulin, iodination of sheep antibody to rabbit IgG, incubation conditions, washing procedures and testing of proinsulin recovery were exactly the same as described for the human proinsulin assay [7].

The mouse proinsulin assay was performed using serial dilutions of a mouse b-component produced in our laboratory as standard. The concentrations of mouse proinsulin standards were from $0.006-0.235 \mathrm{pmol} / \mathrm{ml}$. Rabbit anti-rat C-peptide was used in a dilution of $1 / 1000$. The assay procedures were identical to the rat proinsulin assay.

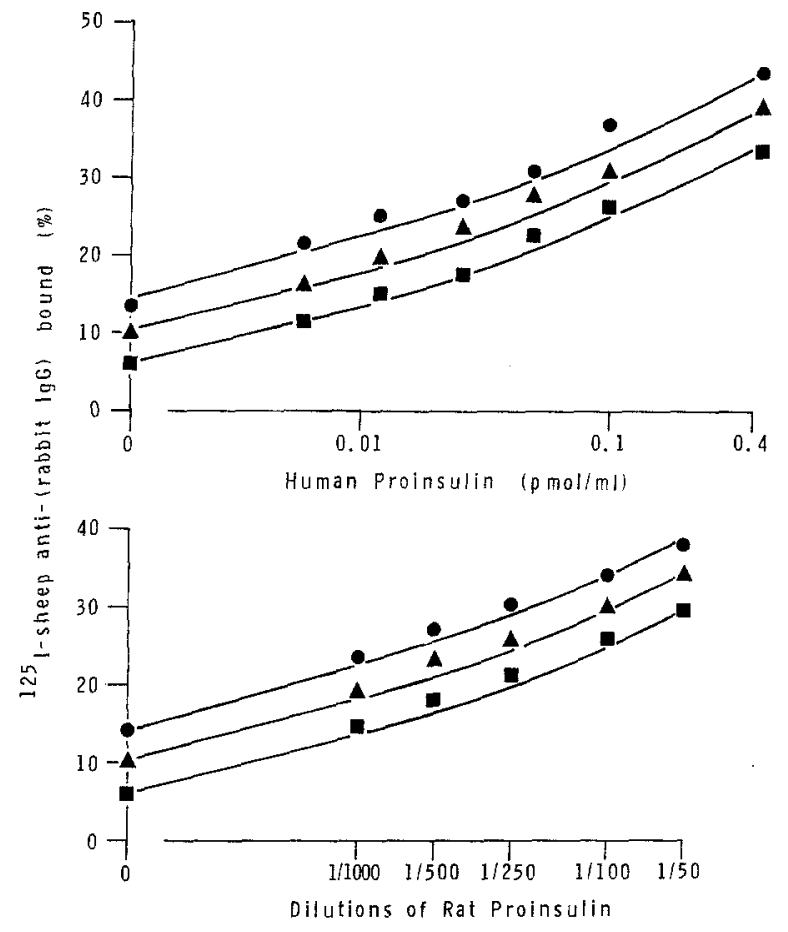

Fig. 2. Three individual standard curves of the human and rat proinsulin assays at different dilution $(\mathbf{1} / 250 ; \boldsymbol{\Delta} 1 / 500$; $\boldsymbol{D}_{1 / 1000)}$ of rabbit antisera to C-peptide. In each assay the total radioactivity was 10,000 c. p.m.

\section{Rat Proinsulin Standard}

The extraction procedure for rat proinsulin and insulin was modified from a method for the isolation of insulin from a single cat pancreas [10]. Ten male Wistar rats $(200-300 \mathrm{~g})$ were killed by a blow on the head and pancreata immediately removed and minced to small pieces $(2-3 \mathrm{~mm})$ in $27 \mathrm{ml}$ of acid-ethanol extraction fluid at $4{ }^{\circ} \mathrm{C}(375 \mathrm{ml}$ of $95 \%$ ethanol and $7.5 \mathrm{ml}$ of concentrated $\mathrm{HCl})$. Distilled water was added to bring the total volume to $40 \mathrm{ml}$. The entire mixture was then homogenized with a Polytron (Kinematica $\mathrm{GmbH}$, Switzerland) for $1 \mathrm{~min}$ and then allowed to stand at $4{ }^{\circ} \mathrm{C}$ for $4 \mathrm{~h}$. After centrifugation at $2500 \mathrm{~g}$ for $15 \mathrm{~min}$ the precipitate was discarded and the supernatant adjusted to $\mathrm{pH} 8.2$ with $\mathrm{NH}_{4} \mathrm{OH}$ (sp. gr. 0.88). After a further centrifugation at $2500 \mathrm{~g}$ for $15 \mathrm{~min}$ the precipitate was discarded and $0.75 \mathrm{ml}$ of ammonium acetate buffer ( $2 \mathrm{~mol} / 1, \mathrm{pH}$ adjusted to 5.3 with acetic acid $2 \mathrm{~mol} / \mathrm{l})$ added. The $\mathrm{pH}$ of the supernatant was finally adjusted to 5.3 with $4 \mathrm{~mol} / 1 \mathrm{HCl}$. A further 2 volumes of absolute ethanol and $4 \mathrm{vol}-$ umes of anhydrous ether were added and the mixture allowed to stand overnight at $4^{\circ} \mathrm{C}$. The precipitate formed was dissolved in $2 \mathrm{ml}$ of acetic acid $(1 \mathrm{~mol} / \mathrm{l})$ and then dialysed against the same acid for $24 \mathrm{~h}$. A $0.5 \mathrm{ml}$ aliquot of the extract was applied to a Sephadex G 50 column $(85 \times 1.5 \mathrm{~cm})$ and eluted with acetic acid $(1 \mathrm{~mol} / \mathrm{l})$. Fractions of $4.7 \mathrm{ml}$ were collected and dialysed for $24 \mathrm{~h}$ against PBS and assayed for rat proinsulin and rat insulin immunoreactivity. The second peak of insulin immunoreactivity corresponding to the b-component of crude insulin [5] also contained proinsulin immunoreactivity and was used as the proinsulin standard.

As there was no absolute standard for calibration the proinsulin concentration of this rat b-component was estimated in the following manner. Human and rat proinsulin assays were both performed at three different concentrations of rabbit antiserum to 
the C-peptide of the respective species $(1 / 1000,1 / 500$ and $1 / 250)$. Antibody-coated tubes of high insulin binding capacity $(0.33 \mathrm{pmol} /$ tube) and known to achieve greater than $90 \%$ recovery of proinsulin at an insulin concentration of $2.76 \mathrm{pmol} / \mathrm{ml}$ were used in this assay. Human proinsulin standards were between $0.006-0.4 \mathrm{pmol} /$ $\mathrm{ml}$ and rat proinsulin standards were in a serial dilution $(1 / 50-1 / 1000)$ of the b-component produced in our laboratory. All samples were below $0.67 \mathrm{pmol} / \mathrm{ml}$ in insulin immunoreactivity. Under these experimental conditions, provided that the rabbit antiserum to $\mathrm{C}$ peptide is present in considerable excess, an equimolar amount of rat or human proinsulin adsorbed on to the antibody-coated tubes should combine with an equal quantity of rabbit antibody to Cpeptide which in turn will combine with an equal quantity of sheep antibody to rabbit $\operatorname{IgG}$. Consequently, the molar concentration of rat proinsulin in a particular dilution of the b-component is the same as the molar concentration of human proinsulin which produced the same uptake of ${ }^{125}$ I-sheep antibody to rabbit IgG. By comparing all the points on the rat proinsulin standard curves with the human proinsulin standard curves a mean estimate of the rat proinsulin concentration in our b-component could be obtained.

\section{Mouse Proinsulin Standard}

An acid-ethanol extract of mouse pancreas was produced from 12 pancreata of adult female $T-0$ mice. The extraction and chromatographic procedures were as described for the rat proinsulin standard except that the volume of extraction fluid was reduced by $50 \%$. A fraction of the mouse b-component was used as standard in the mouse proinsulin assay and mouse proinsulin concentration of this fraction was determined by calibration against rat proinsulin as standard.

\section{Intravenous Glucose Tolerance Tests in Rats}

Five male Wistar rats $(200-300 \mathrm{~g})$ were fasted overnight and anaesthetised with ether. The jugular vein was exposed and a plastic cannula inserted and left in situ. A $10 \mathrm{~g} / 100 \mathrm{ml}$ solution of glucose was administered as a bolus $(0.15 \mathrm{~g} /$ animal $)$. Blood was collected from the cannula at zero time and at 2, 5, 15 and $45 \mathrm{~min}$ after glucose injection. Blood was collected in heparinised tubes. Plasma was separated by centrifugation immediately and frozen at $-20^{\circ} \mathrm{C}$ until assayed. Insulin was measured by radioimmunoassay [11] and calculation of the proinsulin/insulin molar ratio was as described previously [7] assuming that rat proinsulin is $50 \%$ as reactive as rat insulin in the insulin immunoassay. In our insulin radioimmunoassay human proinsulin was found to be $50 \%$ as immunoreactive as human insulin [7].

\section{Effects of Oral Glucose in Mice}

Adult female T-O mice were fasted and withheld from water for $24 \mathrm{~h}$ and then caged in pairs. Each pair was then fed either a $20 \mathrm{~g} /$ $100 \mathrm{ml}$ solution of glucose or water. The time of ingestion was noted and blood was collected $30 \mathrm{~min}$ afterwards from an axillary vein. The blood was allowed to clot and the serum was frozen at $-20^{\circ} \mathrm{C}$ until assayed.

\section{Glucose Stimulation of Isolated Rat Islets of Langerhans}

Islets of Langerhans were isolated from pancreata of fed male Wistar rats $(200-300 \mathrm{~g})$. The technique was based on that of Lacy and Kostianovsky [12]. All procedures were carried out in KrebsRinger bicarbonate buffer [13] with added Hepes (25 mmol/l)

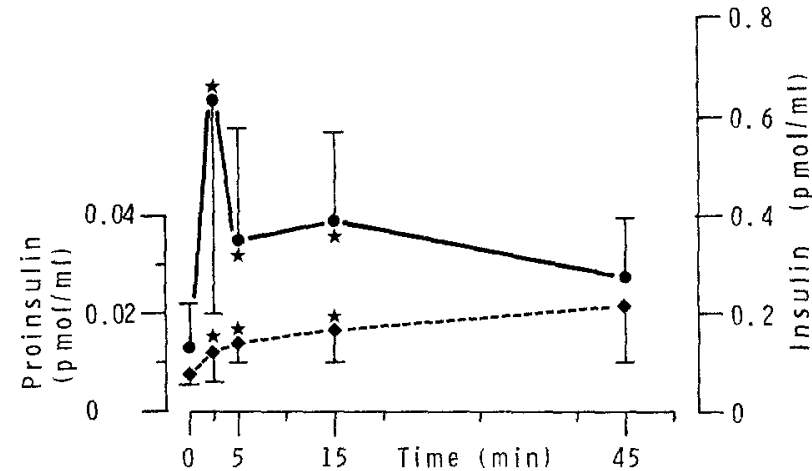

Fig. 3. Plasma insulin and proinsulin concentrations in rats during intravenous glucose tolerance tests, for details see text. insulin; proinsulin; *Significantly different from concentration at zero time $(\mathrm{P}<0.05)$

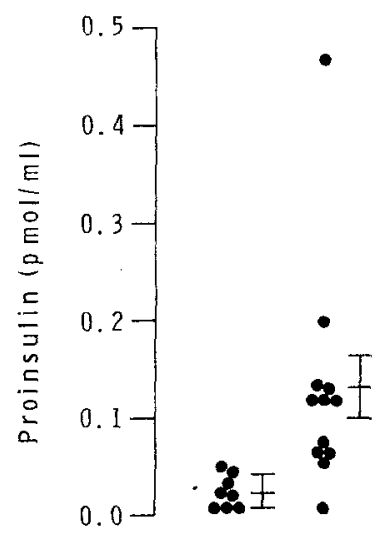

Control Glucose
Fig. 4. Serum proinsulin concentrations of mice 30 min after ingestion of water (control) or glucose solution. Each point represents 1 animal
(KRB-H buffer). The buffer was gassed with $95 \% \mathrm{O}_{2}$ and $5 \% \mathrm{CO}_{2}$ and $\mathrm{pH}$ adjusted to 7.4. Pancreata from several rats were pooled, finely minced with scissors and divided into $2 \mathrm{ml}$ aliquots each containing the equivalent of one pancreas. This was added to collagenase (10 mg) and incubated at $37^{\circ} \mathrm{C}$ in a Dubnoff shaker with continuous shaking for $30 \mathrm{~min}$. The mixture was shaken briskly for 30 seconds every 7 min with a mechanical vibrator. Afterwards collagenase was removed by washing three times in KRB-H buffer. Intact islets were hand-picked with a Pasteur pipette under a dissecting microscope.

In the glucose stimulation experiments, batches of 10 islets were incubated at $37^{\circ} \mathrm{C}$ in $1 \mathrm{ml}$ of KRB-H buffer. The incubation buffer was at a glucose concentration of either $3 \mathrm{mmol} / \mathrm{l}$ (low glucose) or $20 \mathrm{mmol} / 1$ (high glucose) and each incubation period was $30 \mathrm{~min}$. The first incubation period was always in low glucose. Subsequently, the batches of 10 isiets were divided into three groups. In the intermittent high glucose stimulation group the islets were incubated alternately in low and high glucose. In the continuous stimulation group the islets were incubated in high glucose for every period. Control islets were incubated in low glucose throughout. All islets were incubated for at least four periods; in 10 batches of 10 islets (intermittent stimulation $n=3$, continuous stimulation $n=3$, control $n=4$ ) the incubation periods were extended to seven. The incubation media were removed and frozen at $-20^{\circ} \mathrm{C}$ immediately. The measurement of insulin, proinsulin and calculation of proinsulin/insulin ratios were performed as 
Table 1. Recovery of proinsulin at various insulin concentrations using antibody-coated tubes of different insulin binding capacity

\begin{tabular}{|c|c|c|c|}
\hline \multirow[t]{2}{*}{$\begin{array}{l}\text { Insulin } \\
\text { concentration }^{\mathrm{a}} \\
\text { in } 50 \mu \mathrm{l} \text { sample } \\
(\mu \mathrm{U} / \mathrm{ml})\end{array}$} & \multicolumn{3}{|c|}{$\begin{array}{l}\text { Recovery of added proinsulin using } \\
\text { antibody-coated tubes of different } \\
\text { insulin binding capacity (\%) }\end{array}$} \\
\hline & $\begin{array}{l}\text { Binding capacity } \\
1.17 \mathrm{pmol} / \text { tube }\end{array}$ & $0.33 \mathrm{pmol} / \mathrm{tube}$ & $0.17 \mathrm{pmol} / \mathrm{tube}$ \\
\hline 4.8 & 100 & - & - \\
\hline 2.67 & 100 & 92 & 80 \\
\hline 1.33 & 100 & 100 & 85 \\
\hline 0.67 & 100 & 100 & 100 \\
\hline
\end{tabular}

a The actual amount of insulin present in the assay tube in pmol was $1 / 20$ of this figure

described previously [7]. Recoveries of proinsulin and insulin in this system were tested by incubating a known quantity of each peptide for $30 \mathrm{~min}$ in incubation media obtained from the first and seventh incubation periods.

\section{Extraction of Proinsulin and Insulin from Isolated Islets}

Batches of 20 isolated islets were homogenised manually in a small glass homogenizer in $2 \mathrm{ml}$ of acid-ethanol extraction fluid. The mixture was allowed to stand at $4^{\circ} \mathrm{C}$ for $24 \mathrm{~h}$ and then dialysed against PBS for $24 \mathrm{~h}$ before assay for insulin and proinsulin immunoreactivity.

\section{Statistical Methods}

Results are expressed as mean \pm SEM. Statistical comparisons were performed by Wilcoxon-rank sum test.

\section{Results}

\section{Proinsulin Standard}

The elution of the acid-ethanol extract of rat pancreata on Sephadex G 50 chromatography is shown in Fig. 1. Three peaks of insulin immunoreactivity, corresponding to the $\mathrm{a}, \mathrm{b}$ and $\mathrm{c}$-components of crude insulin [8], could be recognised. Rat proinsulin. immunoreactivity was in the b-component with an elution volume identical to that of porcine proinsulin. Fraction No. 16 was used as standard material in all subsequent rat proinsulin assays. This fraction diluted in parallel with the Novo rat b-component in the rat proinsulin assay. The absolute concentration of rat proinsulin in Fraction No. 16 was estimated to be $6.72 \mathrm{pmol} / \mathrm{ml}$ from results to be discussed in the next section. Using this figure the mean proinsulin content of two different acid-ethanol extracts of rat pancreas was estimated to be $4.95 \%(n=2,4.40$ and
5.50) of the total amount of insulin and proinsulin present; agreeing well with a mean of $5.45 \%(n=2$, 5.10 and 5.80 ) when two acid-ethanol extracts of 20 isolated islets were measured. The elution pattern of mouse pancreatic extract was similar to that of the rat. A fraction of the mouse b-component was used as standard in the mouse proinsulin assay.

\section{Standard Curve}

The standard curves of the rat and human proinsulin assays are shown in Fig. 2. The rat proinsulin standards were serial dilutions of Fraction No. 16 ranging from $1 / 50$ to $1 / 1000$; the human proinsulin standards employed were between $0.006-0.4 \mathrm{pmol} / \mathrm{ml}$. Each assay was performed at three different concentrations of rabbit antiserum to $C$-peptide raised against the respective C-peptide $(1 / 1000,1 / 500$ and $1 / 250)$. The non-specific binding increased progressively with the concentration of rabbit antiserum to C-peptide. However, within each species the three curves were completely parallel over the concentrations of proinsulin examined; suggesting that even at an antiserum dilution of $1 / 1000$ the proinsulin molecules bound to the antibody-coated tubes were saturated with rabbit antibody to C-peptide. If it is assumed that a given increase in binding of label is produced by an identical amount of rabbit IgG bound to proinsulin and hence by an identical amount of proinsulin then it is possible to calculate the amount of proinsulin present in the rat standard from the human proinsulin curves. By comparing all points on the rat proinsulin standard curves with the human proinsulin standard curves it was estimated that Fraction No. 16 contained 6.72 $\pm 0.50 \mathrm{pmol} / \mathrm{ml}$ of rat proinsulin (mean of two experiments). The mouse proinsulin standard diluted in parallel with the rat proinsulin standard and when calibrated against the latter was estimated to contain $2.35 \pm 0.30 \mathrm{pmol} / \mathrm{ml}$ of mouse proinsulin.

\section{Sensitivity and Specificity}

The detection limit of the rat and mouse proinsulin assays was $0.006 \mathrm{pmol} / \mathrm{ml}$; similar to that of the human proinsulin assays reported previously [7]. Human proinsulin $(0.10 \mathrm{pmol} / \mathrm{ml})$ and porcine proinsulin $(1.37 \mathrm{pmol} / \mathrm{ml})$ did not react in the rat proinsulin assay. Bovine proinsulin $(0.08-1.37 \mathrm{pmol} / \mathrm{ml})$ showed a mean cross-reactivity of $8 \%$ but did not dilute in parallel with the rat proinsulin standard.

\section{Recovery}

The recovery of proinsulin at different rat insulin concentrations is shown in Table 1 . Recovery was 
Table 2. The effects of intermittent or continuous high glucose stimulation on insulin and proinsulin secretion of isolated islets

\begin{tabular}{|c|c|c|c|c|c|}
\hline \multirow[t]{2}{*}{ Group } & & \multicolumn{4}{|c|}{ Incubation period ${ }^{a}$} \\
\hline & & 1 & 2 & 3 & 4 \\
\hline \multirow{3}{*}{$\begin{array}{l}\text { Intermittent } \\
(n=6)\end{array}$} & $\begin{array}{l}\text { Insulin } \\
(\mathrm{pmol} / \mathrm{ml})\end{array}$ & $1.15 \pm 0.15$ & $2.55 \pm 0.34^{b}$ & $1.95 \pm 0.50^{\mathrm{b}}$ & $3.65 \pm 0.53^{b}$ \\
\hline & $\begin{array}{l}\text { Proinsulin } \\
(\mathrm{pmol} / \mathrm{ml})\end{array}$ & $0.021 \pm 0.004$ & $0.023 \pm 0.006$ & $0.021 \pm 0.002$ & $0.035 \pm 0.009^{b}$ \\
\hline & $\frac{\text { Proinsulin }}{\text { Insulin }}$ & $0.019 \pm 0.002$ & $0.009 \pm 0.002^{\mathrm{b}}$ & $0.018 \pm 0.002$ & $0.016 \pm 0.003$ \\
\hline \multirow{3}{*}{$\begin{array}{l}\text { Continuous } \\
(n=6)\end{array}$} & $\begin{array}{l}\text { Insulin } \\
(\mathrm{pmol} / \mathrm{ml})\end{array}$ & $1.01 \pm 0.17$ & $1.56 \pm 0.15^{\mathrm{b}}$ & $2.27 \pm 0.20^{\mathrm{b}}$ & $3.78 \pm 0.70^{\mathrm{b}}$ \\
\hline & $\begin{array}{l}\text { Proinsulin } \\
(\mathrm{pmol} / \mathrm{ml})\end{array}$ & $0.021 \pm 0.007$ & $0.017 \pm 0.002$ & $0.025 \pm 0.006$ & $0.050 \pm 0.014^{b}$ \\
\hline & $\frac{\text { Proinsulin }}{\text { Insulin }}$ & $0.020 \pm 0.004$ & $0.011 \pm 0.002^{\mathrm{b}}$ & $0.011 \pm 0.002^{\mathrm{b}}$ & $0.020 \pm 0.004$ \\
\hline
\end{tabular}

a Islets were incubated in batches of 10 and each incubation was $30 \mathrm{~min}$. In the intermittent stimulation group incubation periods 1 and 3 were in low glucose $(3 \mathrm{mmol} / \mathrm{l})$ and periods 2 and 4 were in high glucose $(20 \mathrm{mmol} / \mathrm{l})$. In the continuous stimulation group incubation period 1 was in low glucose and incubation periods 2,3 and 4 in high glucose

b Significantly different from the corresponding parameter in the first incubation period $(\mathrm{P}<0.05)$

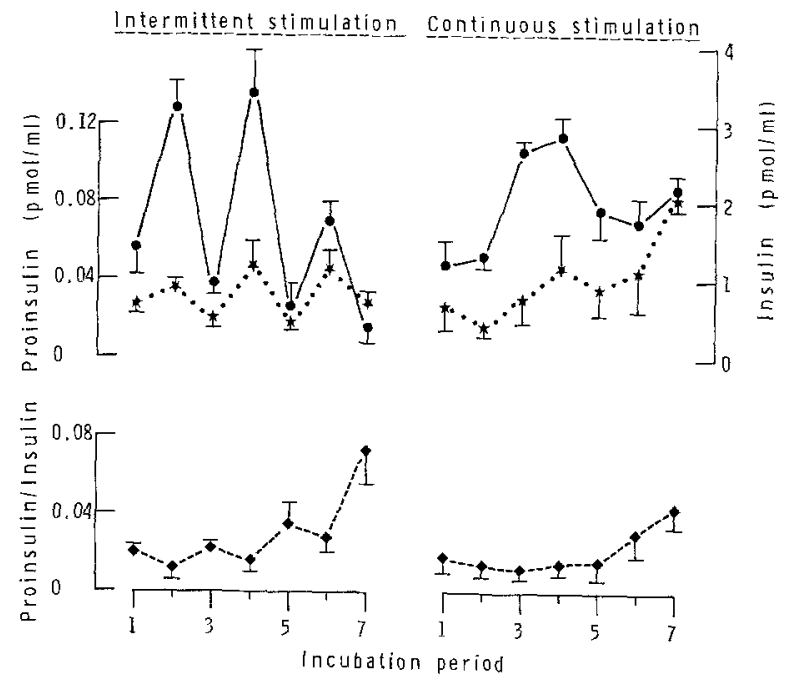

Fig. 5. The insulin and proinsulin secretions and proinsulin/insulin ratios of isolated rat islets ( $\mathrm{n}=3$ batches of islets) during prolonged high glucose stimulation. In the intermittent stimulation group periods $1,3,5$ and 7 were in low glucose and other periods in high glucose. In the continuous stimulation group period 1 was in low glucose and the other periods in high glucose. insulin; * proinsulin

adequate when the insulin binding capacity of the tubes was at least 5 fold in excess of the total insulin present in the sample. Measurements of proinsulin in plasma were performed with tubes of binding capacity greater than $0.33 \mathrm{pmol} /$ tube and all samples were diluted to an insulin immunoreactivity of less than $1.33 \mathrm{pmol} / \mathrm{ml}$ before assay. Tubes of high binding capacity $(1.17 \mathrm{pmol} /$ tube $)$ were required in the experiments on isolated islets as the insulin concentrations in the incubation media were usually higher than those normally found in plasma. All samples were diluted to an insulin immunoreactivity of less than $2.67 \mathrm{pmol} / \mathrm{ml}$ before assay.

\section{Proinsulin after Glucose in Mouse and Rat}

The mean insulin and proinsulin responses of five rats during intravenous glucose tolerance tests are shown in Fig. 3. There was a biphasic insulin secretion reaching a maximum at 2 min after glucose injection. Proinsulin rose more gradually from 0.008 $\pm 0.002 \mathrm{pmol} / \mathrm{ml}$ initially to reach significantly higher concentrations at 2,5 and $15 \mathrm{~min}$. The mean proinsulin/insulin ratio was 0.06 under basal conditions. This fell to 0.02 at $2 \mathrm{~min}$ and then progressively increased to 0.08 at $45 \mathrm{~min}$. In the twelve glucose-fed mice the mean proinsulin concentration was $0.132 \pm$ $0.036 \mathrm{pmol} / \mathrm{ml}$; significantly higher than $0.019 \pm$ $0.006 \mathrm{pmol} / \mathrm{ml}$ in the eight control mice fed only water $(\mathrm{p}<0.05)$ (Fig. 4).

\section{Proinsulin Release from Rat Islets}

The effects of either intermittent or continuous high glucose stimulation on isolated rat islets are shown in Table 2. In all islets examined, there was an initial fall in the proinsulin/insulin ratio followed by a gradual return to basal values. The results of a small number of islets subjected to prolonged stimulation tests are shown in Fig. 5. Irrespective of whether the high glucose stimulus had been intermittent or continuous 
there was a fall in insulin secretion after the fourth period of incubation. Proinsulin secretion, however, did not show the same decline and in the group maintained on high glucose stimulation continued to rise. The proinsulin/insulin ratio, after an initial decline, rose to 3.8 and 2.2 fold of the basal values in the intermittent and continuous stimulation groups respectively. Control islets incubated continuously in low glucose showed a gradual decline in proinsulin and insulin secretion to $50 \%$ and $40 \%$ of the initial secretion respectively. The proinsulin/insulin ratio changed insignificantly from 0.025 to 0.029 . The recoveries of insulin or proinsulin added to the incubation media were greater than $90 \%$ both at the first and the seventh period of the prolonged stimulation experiments.

\section{Discussion}

Rat and mouse are used extensively as laboratory models for the investigation of diabetes mellitus. However, there have been very few studies of proinsulin secretion in these animals due mainly to the lack of a convenient assay. In an investigation in which rat proinsulin secretion was studied in a perifusion system [4], it was necessary to concentrate the perifusate and separate proinsulin from insulin by chromatography prior to insulin assay. This technique is relatively tedious and required a large volume of sample for analysis. Furthermore, it was found that the procedure was not sufficiently sensitive to permit measurement of proinsulin secretion from unstimulated pancreas. Consequently, only selected samples were analysed for proinsulin content. The synthesis and release of rat proinsulin has also been examined by using tritiated leucine as a marker [13]. In this system only newly synthesised polypeptides will be detected and again chromatography had to be used to separate proinsulin from insulin. A specific proinsulin assay which can be applied, without preliminary removal of insulin, to a large number of samples would facilitate the study of rat and mouse proinsulin.

The indirect two-site immunoradiometric assay for rat and mouse proinsulin described in this study is an adaptation of a human proinsulin assay [7]. The substitution of rabbit antibody to human C-peptide used in the human proinsulin assay by a rabbit antibody to rat $\mathrm{C}$-peptide permits the measurement of rat proinsulin with otherwise identical reagents. The rabbit antiserum used in this study was raised against rat C-peptide II. It cross-reacted with both rat Cpeptides in radioimmunoassays in which either $\mathrm{C}$ peptide was labelled, but not identically under all conditions. Therefore in the absence of pure samples of the two rat proinsulins it is impossible to be certain what their relative reactivity was in the present assay or the reactivity of rat insulin proinsulin intermediates. In the discussion which follows it is assumed that the changes in rat proinsulin detected reflect changes in total rat proinsulin. Due to the difficulty of sampling large volumes of blood from small laboratory animals it was necessary to scale down the incubation volume from $200 \mu \mathrm{l}$ as described for the human proinsulin assay to $50 \mu \mathrm{l}$ in this instance. There did not appear to be a loss of sensitivity when the smaller incubation volume was employed; standard curves set up with either $200 \mu \mathrm{l}$ or $50 \mu \mathrm{l}$ samples were completely superimposable. The proinsulin extracted from 10 rat pancreata is sufficient for approximately 300 standard curves and $1 \mathrm{ml}$ of rabbit antiserum to rat C-peptide is adequate for 20,000 assay tubes. The rat proinsulin assay did not detect either human or porcine proinsulins. There was a slight cross-reaction with bovine proinsulin but there was a difference in the behaviour of rat and bovine proinsulins on serial dilution.

Although the amino acid sequences of mouse proinsulin I and II are not known they are probably similar to those of the rat proinsulins; as demonstrated by the parallel dilutions of proinsulins of these two species in the proinsulin assay. Using the rat proinsulin assay it was possible to detect in mouse a change in plasma proinsulin concentration induced by glucose ingestion.

The determination of the absolute concentration of proinsulin in the rat b-component posed a special problem as there was no available standard of pure rat proinsulin. The amount of material produced from 10 pancreata was insufficient for protein purity determination on polyacrylamide gel electrophoresis. Our method of calibrating rat proinsulin against the human proinsulin standard assumed that the guineapig antibody to insulin behaved identically towards rat and human proinsulins under the experimental conditions used and that the proinsulin molecules adsorbed on to the coated tubes were saturated with rabbit antibody to $\mathrm{C}$-peptide. As the antibody-coated tubes used had a binding capacity greatly in excess of the proinsulin and insulin bound the effect of any possible difference in the affinities of rat and human proinsulins for the guinea-pig antibody to insulin would be expected to be minimised. The latter assumption appeared to be justified by the observation that when the rabbit antisera to C-peptide concentrations were increased progressively, the curves remained parallel with no increase in specific binding. This suggests that, at the range of proinsulin concentration examined, most adsorbed proinsulin had indeed combined with a rabbit antibody to C-pep- 
tide. Using the estimated proinsulin concentration of $6.72 \mathrm{pmol} / \mathrm{ml}$ in the rat b-component, the proportion of proinsulin in rat pancreatic extract and the circulating proinsulin concentration in rats appeared to be in reasonable agreement with those published for other species [5]. Although a lower content of proinsulin in rat pancreas had been reported previously [4], these authors measured proinsulin against an insulin standard and would be expected to underestimate the proinsulin content.

It is necessary to ensure that recovery of rat proinsulin is adequate at a high concentration of rat insulin which would compete for the binding sites of the guinea-pig antibody to insulin. This is especially difficult to achieve in the experiments with isolated islets as the insulin concentration in the incubation medium is often considerably higher than that found in plasma. Furthermore, the proinsulin/insulin ratio is low since the longer in vivo half life of proinsulin, which normally serves to increase the proinsulin/ insulin ratio in the peripheral circulation, would not be operative in this in vitro situation. In practice it was found satisfactory to use antibody-coated tubes of higher binding capacity than those employed for measuring plasma proinsulin and to dilute the samples to approximately $2.67 \mathrm{pmol} / \mathrm{ml}$ of insulin.

The glucose tolerance tests in rats showed that, as in man, the rise in proinsulin concentration is relatively slow in comparison with insulin [8]; consequently the proinsulin/insulin ratio showed an initial fall before returning to basal value. This pattern of proinsulin secretion was also observed in the in vitro islet experiments in which significant increases in proinsulin secretion did not occur until the fourth period of incubation. There was initially a proportionally higher release of insulin with a fall in proinsulin/insulin ratio. Upon more prolonged high glucose stimulation proinsulin secretion was sustained at the same rate or continued to rise while insulin secretion was beginning to decline. Consequently proinsulin became more important as a secretory product of the $\beta$ cell. This observation is in agreement with previous findings $[4,15]$ but the mechanism of the increase is not known. It is unlikely to be due to a faster degradation of insulin after prolonged stimulation of the islets as recoveries of proinsulin and insulin approached $100 \%$ both at the beginning and at the end of the prolonged stimulation experiment. It may represent secretion of less mature $\beta$ granules with a higher proportion of proinsulin. It is also possible that there is exhaustion of a glucose-induced mechanism responsible for the conversion of proinsulin to insulin with preferential secretion of the latter. The observed alteration in the relative secretory rate of proinsulin and insulin may contribute to the changes in the proinsulin/insulin ratio detected during a glucose tolerance test [16]. This phenomenon has thus far been attributed to the difference in the half-lives of proinsulin and insulin. An increase in proinsulin secretion has been reported in juvenile diabetes [1] and attributed to the inability of $\beta$ cells to arrange the proinsulin in secretory granules for adequate conversion of proinsulin to insulin. As diabetes is not a feature of the syndrome of familial hyperproinsulinaemia [17] and proinsulin secretion can be increased by a persistant glucose challenge the hypersecretion of proinsulin is more likely to be the result rather than the cause of the hyperglycaemia.

Acknowledgements. We wish to thank Dr. A. Rubenstein for the human proinsulin; Dr. R. Chance for the porcine and bovine proinsulins; Dr. Lise Heding for the rat b-component and rat insulin. D.K. Yue was supported by The Coppleson Postgraduate Medical Foundation of N. S. W.; The Beecham Travelling Fellowship of the Royal Australasian College of Physicians; The Nuffield Foundation and the Susman Bequest of the University of Sidney, O. M. Gibby was supported by Novo Laboratories Ltd., U. K. and S. D. Luzio by Dr. Karl Thomae GmbH, Biberach an der Riss. We are also grateful to the British Diabetic Association for financial support.

\section{References}

1. Heding, L. G.: Specific and direct radioimmunoassay for human proinsulin in serum. Diabetologia 13, 467-474 (1977)

2. Rosenbloom, A. L., Starr, J. I., Juhn, D., Rubenstein, A. H.: Serum proinsulin in children and adolescents with chemical diabetes. Diabetes 24. 753-757 (1975)

3. Melani, F., Rubenstein, A.H., Oyer, P.E., Steiner, D. F.: Identification of proinsulin and $\mathrm{C}$-peptide in human serum by a specific immunoassay. Proc. Natl. Acad. Sci. USA 67, $148-155$ (1970)

4. Burr, I.M., Stauffacher, W., Balant, L., Renold, A. E., Grodsky, G.: Dynamic aspects of proinsulin release from perifused rat pancreas. Lancet 1969 II, 882-883

5. Rubenstein, A.H., Melani, F., Steiner, D. F.: Circulating proinsulin: immunology, measurement, and biological activity. In: Handbook of physiology. Vol. I. Steiner, D. F., Freinkel, N. (Eds.), pp. 515-528. Baltimore: Williams and Wilkins 1972

6. Steiner, D. F.: On the role of the proinsulin C-peptide. Diabetes 27 [Suppl. 1], 145-148 (1978)

7. Rainbow, S. J., Woodhead, J.S., Yue, D. K., Luzio, S. D., Hales, C. N.: Measurement of human proinsulin by an indirect two-site immunoradiometric assay. Díabetologia 17, 229-234 (1979)

8. Yanaihara, N., Yanaihara, C., Sakagami, M., Sakura, N., Hashimoto, T., Nishida, T.: Syntheses of C-peptides and human proinsulin. Diabetes 27 [Suppl. 1], 149-160 (1978)

9. Steiner, D. F., Hallund, O., Rubenstein, A., Cho, S., Bayliss, C.: Isolation and properties of proinsulin, intermediate forms, and other minor components from crystalline bovine insulin. Diabetes 17, 725-736 (1978)

10. Davoren, P. R.: The isolation of insulin from a single cat pancreas. Biochim. Biophys. Acta 63, 150-153 (1962)

11. Hales, C. N., Randle, P. J.: Immunoassay of insulin with insulin-antibody precipitate. Biochem. J. 88, 137-146 (1963) 
12. Lacy, P.E., Kostianovsky, M.: Method for the isolation of intact islets of Langerhans from the rat pancreas. Diabetes 16, 35-39 (1967)

13. Krebs, H. A., Henseleit, K.: Untersuchungen über die Harnstoffbildung im Tierkörper. Hoppe Seylers Z. Physiol. Chem. 210, 33-66 (1932)

14. Tanese, T., Lazarus, N. R., Devrim, S., Recant, L.: Synthesis and release of proinsulin and insulin by isolated rat islets of Langerhans. J. Clin. Invest. 49, 1394-1404 (1970)

15. Track, N. S., Frerichs, H., Creutzfeldt, W.: Release of newly synthesized proinsulin and insulin from granulated and degranulated isolated rat pancreatic islets. The effect of high glucose concentration. Horm. Metab. Res. [Suppl.] 5, 97-103 (1974)

16. Horwitz, D. L., Starr, J. I., Mako, M. E., Blackard, W. G., Rubenstein, A. H.: Proinsulin, insulin, and C-peptide concen- trations in human portal and peripheral blood. J. Clin. Invest.

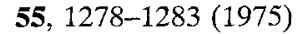

17. Gabbay, K.H., Deluca, K., Fisher, J. N., Mako, M.E., Rubenstein, A. H.: Familial hyperproinsulinaemia: An autosomal dominant defect. N. Engl. J. Med. 294, 911-915 (1976)

Received: December 18, 1978

and in revised form: June 18,1979

Prof. C. N. Hales

University of Cambridge

Department of Clinical Biochemistry

Addenbrooke's Hospital

Hills Road

Cambridge CB2 20R

England 